\title{
RESTAURAÇÕES DE LESÕES DE EROSÃO EXÓGENA COM FACETAS DIRETAS EM RESINA COMPOSTA
}

Jean Felipe Garlet WERLANG, Daiane Weckerlim Fernandes NONATO, Ricardo Yutaca MASSAKI, Paulo César Gonçalves dos SANTOS, Rafael Torres BRUM

Paciente do sexo masculino, 25 anos, após um longo período sem atendimento odontológico, foi indicado para a clínica de especialização em Dentística da UFPR apresentando desgastes dentários, que comprometiam a estética. Ao exame clínico constataram-se lesões não cariosas relacionadas à ingestão de substâncias ácidas dos caninos e incisivos superiores, apresentado regiões com dentina exposta. Foi proposto a realização de tratamento com facetas diretas em resina composta fotopolimerizável, confeccionadas com máximo de conservação das estruturas dentais remanescentes, utilizando apenas o condicionamento com ácido fosfórico a $37 \%$ e sistema adesivo convencional de 3 passos Adper Scotchbond MultiPurpose (3M Dental Products Division, St Paul, MN, USA) para adesão. A resina composta Filtek Supreme (3MESPE) nas cores A3E e A2E foram usadas para a reconstrução da forma anatômica dos dentes em questão. Para acabamento e polimento foram utilizados lâmina de bisturi 12 nas margens proximais e cervicais, borrachas abrasivas, discos de acabamento Soflex (3MESPE) e finalizando com feltro e pasta de polimento. A manutenção das restaurações em resina composta com repolimentos e possíveis reparos tornase essencial para a longevidade do tratamento.

Palavras-chave: Erosão dentária, Facetas dentárias, Estética. 